\title{
Nomenclature of factor XI and the contact system
}

\author{
Alvin H. Schmaier ${ }^{1}$ (D) | Jonas Emsley ${ }^{2}$ (D) | Edward P. Feener ${ }^{3}$ (D) | David Gailani $^{4}$ (D) | \\ José W. P. Govers-Riemslag ${ }^{5}$ | Allen P. Kaplan' ${ }^{6}$ | Coen Maas ${ }^{7}$ iD | \\ James H. Morrissey ${ }^{8}$ (D) | Thomas Renné ${ }^{9}$ | Johannes J. Sidelmann ${ }^{10,11}$ (D) | \\ Joost C. M. Meijers ${ }^{12,13}$
}

${ }^{1}$ Department of Medicine, Hematology and Oncology, University Hospitals Cleveland Medical Center and Case Western Reserve University, Cleveland, OH, USA

${ }^{2}$ School of Pharmacy, Centre for Biomolecular Sciences, University Park, University of Nottingham, Nottingham, UK

${ }^{3}$ KalVista Pharmaceuticals, Inc., Cambridge, MA, USA

${ }^{4}$ Department of Pathology, Microbiology and Immunology, Vanderbilt University Medical Center, Nashville, TN, USA

${ }^{5}$ Departments of Biochemistry and Internal Medicine, Cardiovascular Research Institute Maastricht (CARIM), Maastricht University Medical Center, Maastricht, the Netherlands

${ }^{6}$ The Medical University of South Carolina, Charleston, SC, USA

${ }^{7}$ Department for Clinical Chemistry and Haematology, University Medical Center Utrecht, Utrecht University, Utrecht, the Netherlands

${ }^{8}$ Departments of Biological Chemistry and Internal Medicine, University of Michigan Medical School, Ann Arbor, MI, USA

${ }^{9}$ Institute for Clinical Chemistry and Laboratory Medicine, University Medical Center Hamburg-Eppendorf (UKE), Hamburg, Germany

${ }^{10}$ Unit for Thrombosis Research, Department of Regional Health Research, University of Southern Denmark, Esbjerg, Denmark

${ }^{11}$ Department of Clinical Biochemistry, University Hospital of Southern Denmark, Esbjerg, Denmark

${ }^{12}$ Department of Molecular and Cellular Hemostasis, Sanquin Research, Amsterdam, the Netherlands

${ }^{13}$ Amsterdam UMC, Department of Experimental Vascular Medicine, Amsterdam Cardiovascular Sciences, University of Amsterdam, Amsterdam, the Netherlands

\section{Correspondence}

Alvin H. Schmaier, Case Western Reserve University, 2103 Cornell Road WRB 2-130, Cleveland, OH 44106-7284, USA.

Email:schmaier@case.edu

The contact system (CS) consists of three proteins (factor XII [FXII], prekallikrein $[\mathrm{PK}]$, and $\mathrm{H}$-kininogen [HK, high molecular weight kininogen]) that comprise the initiators of the so-called intrinsic blood coagulation system. The first protein in the hemostatic pathway of intrinsic blood coagulation associated with bleeding is factor XI (FXI), a substrate of FXIla. This report, which is focused on introducing a consensus nomenclature for the three CS proteins and FXI, will describe each protein. However, this consensus report is not intended to be a review of the field; hence, the statements are not referenced. FXII is a zymogen of a serine protease factor XIla (FXIla, EC 3.4.21.38) that becomes an enzyme by autoactivation on artificial and biologic surfaces or by activation by another serine protease such as plasma kallikrein (PKa, EC 3.4.21.34) or plasmin. Plasma PK is a zymogen that is activated to PKa by FXIla and other proteases. PK and FXI circulate and bind to cells in the intravascular compartment

Manuscript handled by: Marc Carrier

Final decision: Marc Carrier, 26 July 2019 in complex with HK. In addition to its carrier function, $\mathrm{HK}$ is a cofactor for FXIla and PKa activities. It is also the parent protein of the vasoactive peptide bradykinin (BK) that is mostly liberated from $\mathrm{HK}$ by $\mathrm{PKa}$. It is well recognized that deficiencies in CS proteins, although having a critical role in in vitro intrinsic blood coagulation assays, such as the activated partial thromboplastin time (aPTT), are not associated with excess bleeding. FXI deficiency is a bleeding state that is called hemophilia $C$.

Recently, there is new-found interest in the CS due to the fact that several biologic substances, both physiologic and pathophysiologic, have been recognized as activators of FXII and, in turn, the intrinsic pathway of blood coagulation. These activators may include microbial membranes, collagen, DNA, polyphosphates, exosomes, and denatured and misfolded proteins. Additionally, when CS protein expression was genetically ablated, FXII, PK, and HK deficient mice have reduced and/or defective vascular occlusion when compared to wild-type animals in a variety of models of arterial and 
TABLE 1 Proposed nomenclature for Factor XI and the Contact System ${ }^{a}$

\begin{tabular}{|c|c|c|}
\hline $\begin{array}{l}\text { Preferred protein } \\
\text { designation }\end{array}$ & Preferred abbreviation & Synonyms \\
\hline \multirow[t]{6}{*}{ H-kininogen } & \multirow[t]{6}{*}{ HK } & High molecular weight kininogen \\
\hline & & High molecular mass kininogen \\
\hline & & HMW kininogen \\
\hline & & $\begin{array}{l}\text { Alpha }_{1} \text {-cysteine proteinase } \\
\text { inhibitor }\end{array}$ \\
\hline & & Alpha $_{1}$-thiol proteinase inhibitor \\
\hline & & Williams or Fitzgerald Factor \\
\hline \multirow[t]{4}{*}{ Cleaved H-kininogen } & \multirow[t]{4}{*}{$\mathrm{CHK}$} & $\begin{array}{l}\text { Cleaved high molecular weight } \\
\text { kininogen }\end{array}$ \\
\hline & & Activated $\mathrm{H}$-kininogen \\
\hline & & Bradykinin-free $\mathrm{H}$-kininogen \\
\hline & & $\mathrm{HKa}$ \\
\hline Bradykinin & $\mathrm{BK}$ & Bk \\
\hline \multirow[t]{4}{*}{ Plasma prekallikrein } & \multirow[t]{4}{*}{ PK } & Prekallikrein \\
\hline & & Plasma prokallikrein \\
\hline & & Fletcher Factor \\
\hline & & PPK \\
\hline \multirow[t]{2}{*}{ Plasma kallikrein } & \multirow[t]{2}{*}{$\mathrm{PKa}$} & Plasma kallikrein \\
\hline & & PK \\
\hline \multirow[t]{3}{*}{ Factor XII } & \multirow[t]{3}{*}{ FXII } & Zymogen Factor XII \\
\hline & & XII, $\alpha$ FXII \\
\hline & & Hageman Factor \\
\hline \multirow[t]{6}{*}{ Factor XIla } & \multirow[t]{2}{*}{ FXIIa } & Activated Factor XII \\
\hline & & Activated Hageman Factor \\
\hline & $\alpha \mathrm{FXIla}$ & $\begin{array}{l}\text { Activated Factor XII with full } \\
\text { heavy chain }\end{array}$ \\
\hline & \multirow[t]{3}{*}{$\beta \mathrm{FXIla}$} & $\begin{array}{l}\text { Activated Factor XII with small } \\
\text { heavy chain }\end{array}$ \\
\hline & & Factor XIla fragment \\
\hline & & Hageman Factor fragment, HFf \\
\hline \multirow[t]{2}{*}{ Factor XI } & \multirow[t]{2}{*}{$\mathrm{FXI}$} & Factor XI \\
\hline & & $\mathrm{XI}$, Rosenthal Factor \\
\hline Factor Xla & FXla & Activated FXI \\
\hline
\end{tabular}

${ }^{a}$ Approved at the meeting of the SSC subcommittee on Factor XI and the Contact System in Dublin, Ireland in 2018. venous thrombosis. These observations suggested that CS proteins may be targets to prevent thrombosis without altering hemostasis. This novel realization has attracted new interest and investigators to the field. As a result, there is a plethora of old and new abbreviations adulterating the literature by the many new investigators resulting in situations in which the reader does not know if the writer is describing a zymogen or active enzyme of a protein. Thus, the Subcommittee on Factor XI and the Contact System agreed at the 62nd Annual ISTH SCC 2016 meeting in Montpellier, France to form a working group to review the nomenclature and recommend abbreviations that can be utilized in communications and investigations. The members of the working group are the authors of this publication. This paper is the first comprehensive report and recommendation of abbreviations for all the CS proteins and FXI. Previously, this subcommittee of the SSC had recommended nomenclature for both HK and L-kininogens (low molecular weight kininogen, LK) and their peptide fragments. ${ }^{1}$ The present report mostly accepts the previous report and builds upon it. The complete recommendations of the abbreviations for all the CS proteins and FXI are shown in Table 1.

Human HK (Table 1) is a single-chain 120 kilodalton (kDa) protein of six domains that when cleaved by PKa consists of a so-called heavy chain of approximately $65 \mathrm{kDa}$ consisting of domains D1D3 and a light chain of approximately $56 \mathrm{kDa}$ (C-terminal domain of D4 and D5 and D6, Figure 1A). PKa cleaves HK liberating the 


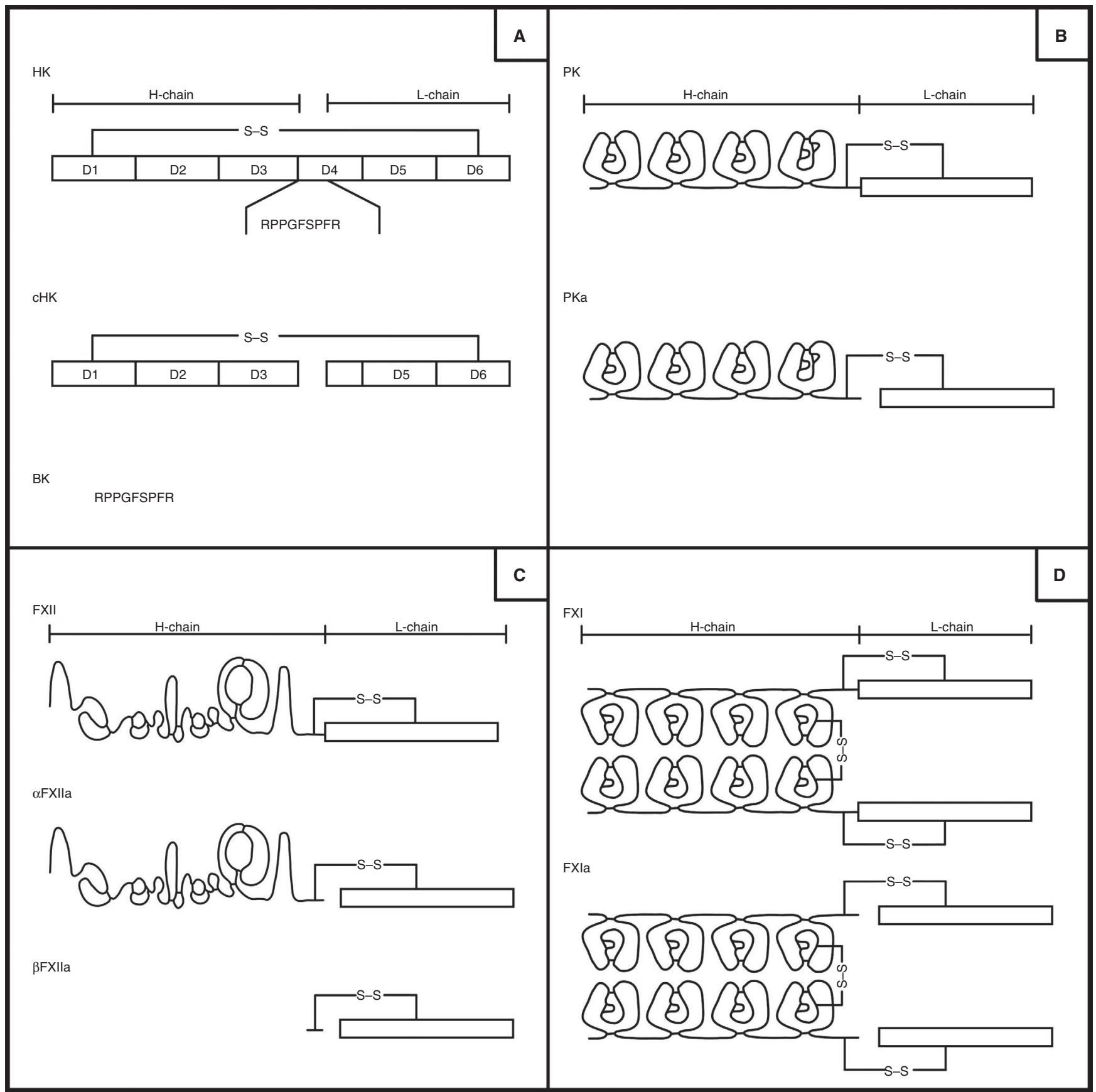

FIG URE 1 Cartoon characterization of each of the proteins of the human contact system. Panel A. The structure of H-kininogen (HK) is shown. It is a single-chain polypeptide consisting of a heavy chain ( $\mathrm{H}$-chain) (domains 1-3) and a light chain (L-chain) (the C-terminal part of domain 4 and domains 5 and 6). Domain 4 consists of the bradykinin (BK) peptide RPPGFSPFR and an additional 12 amino acids at the C-terminus. These latter 12 amino acids of D4 are considered part of the light chain (L-chain) of HK. Domain 5 of HK starts after these 12 amino acids. When cleaved to liberate $\mathrm{BK}$, the residual cleaved $\mathrm{H}$-kininogen (cHK) functions as a biomarker for contact system activation. Panel B. Plasma prekallikrein (PK) is a single-chain zymogen. When activated to a serine protease, plasma kallikrein (PKa) has a heavy (H) and light (L) chain held together by an intramolecular disulfide bond. Panel C. Factor (FXII) also is a single-chain zymogen. When formed into

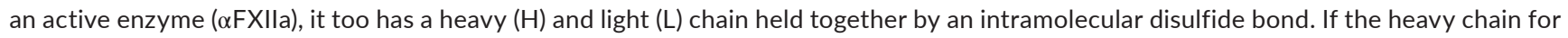
$\alpha \mathrm{FXIla}$ is lost, the enzyme loses its ability to attach to surfaces and becomes a fluid-phase activator ( $\beta$ FXIla) of its substrates. Panel D. Factor $\mathrm{XI}(\mathrm{FXI})$ is a dimer of two single-chain identical polypeptides. Upon activation to factor Xla (FXla), the protein consists of four polypeptides, two heavy $(\mathrm{H})$ and two light $(\mathrm{L})$ chains, held together by intramolecular disulfide bonds

vasoactive peptide bradykinin (BK, Table 1) that consists of 9 amino acids, RPPGFSPFR, from the small 21 amino acid domain 4 of HK (D4, Figure 1A). The residual $\mathrm{HK}$ is called cleaved $\mathrm{HK}(\mathrm{cHK})$ with its heavy and light chains connected by a disulfide bond. Human HK is one of two kininogens ( $\mathrm{HK}$ and $\mathrm{LK}$ ) that arise from a single gene (Kgn1), but alternative splicing in exon 10 produces two proteins. ${ }^{1}$ 
LK has a short light chain and does not bind to PK or FXI and has no procoagulant activity. ${ }^{1}$ As a result, it is not a "classical" member of the CS family and is not considered further in this report. When HK is cleaved and BK is liberated, the residual BK-free $\mathrm{HK}$ has a considerably long half-life in the intravascular compartment compared to the $\mathrm{BK}$ peptide that is degraded within minutes. Cleaved $\mathrm{HK}$ (cHK, Table 1), as detected on immunoblot or ELISA or by its fragments on mass spectrometry, is now recognized as a relatively stable plasma biomarker of prior CS activation (Figure $1 \mathrm{~A}$ ).

Plasma prekallikrein (PK, Table 1) is an $88 \mathrm{kDa}$ single-chain protein zymogen. When $\mathrm{PK}$ is activated to plasma kallikrein (PKa, EC 3.4.21.34), it consists of a $\mathrm{N}$-terminal heavy $(50 \mathrm{kDa}$ ) and $\mathrm{C}$-terminal light (30 kDa) chains (Figure 1B) linked by a disulfide bond. The enzymatic activity of $\mathrm{PKa}$ is contained in its $\mathrm{C}$-terminal light chain (protease domain). The abbreviation PK for plasma prekallikrein was chosen due to its long-standing use and recognition in the field. PK is converted into the serine protease plasma kallikrein (PKa, Table 1) by FXIla. The major substrates of PKa are zymogen FXII and HK. Additional potential substrates of PKa include plasminogen, plasma prorenin, complement factor 3, and protease-activated receptor-1. The activation of FXII by PKa leads to additional PK activation and reciprocal amplification of the entire system. Cleavage of $\mathrm{HK}$ with the liberation of BK results in activation of the plasma kallikrein/kinin system and stimulation of the vasculature's BK receptor system. The abbreviation of PKa for plasma kallikrein was agreed upon because it was the least ambiguous and is consistent with the convention of nomenclature of activated forms of the serine proteases of the plasma blood coagulation system. PK is encoded by the KLKB1 gene and is distinct from other kallikreins including the KLK1 gene product tissue kallikrein, which displays kininogenase activity cleaving LK to generate Lys-bradykinin.

FXII (Table 1) also is a single-chain $80 \mathrm{kDa}$ protein zymogen (Figure 1C). Structurally it is similar to single-chain urokinase and hepatocyte growth factor activator. Following zymogen activation, the active serine protease FXIla consists of a heavy chain of $50 \mathrm{kDa}$ linked to a light chain of $30 \mathrm{kDa}$ by a disulfide bond. The serine protease active site of FXIla is contained in its light chain. When plasma FXII is activated to a serine protease (FXIla, EC 3.4.21.38) (Table 1, Figure $1 C$ ) by PKa or plasmin it acts on various substrates that include PK, FXII, plasminogen, C1r, C1s, and factor VII. It is recognized that there are at least two forms of activated FXII (FXIla). $\alpha \mathrm{FXIla}$ (Table 1 ) retains a fully intact heavy chain (Figure $1 \mathrm{C}$ ). $\beta \mathrm{FXIla}$ (Table 1 ) is also a two-chain protein, but it is missing the majority of its heavy chain and has been called FXIla fragment or Hageman Factor fragment (Figure $1 \mathrm{C}$ ). $\beta$ FXIla has potent enzymatic activity and is a fluid-phase activator of PK and plasminogen. The subcommittee recognizes that much work currently is being performed on FXII as a single-chain protein with detectable enzymatic activity in the absence and presence of surfaces. This area is under active investigation and it was agreed to withhold recommendations of new abbreviation designations for future nomenclature revisions.

FXI (Table 1) is a two-chain $160 \mathrm{kDa}$ protein consisting of two identical $80 \mathrm{kDa}$ chains held together by a single intramolecular disulfide bond, although the disulfide is not essential for it to be a dimer (Figure 1D). Structurally each FXI subunit is similar to $\mathrm{PK}$. When $\mathrm{FXI}$ is activated to an active serine protease ( $\mathrm{FXIa}, \mathrm{EC}$ 3.4.21.27, Table 1) by FXIla or thrombin, each monomer is converted to a heavy chain of $50 \mathrm{kDa}$ and a light chain of $30 \mathrm{kDa}$ (Figure 1D) that remain connected by a disulfide bond. The serine protease active sites of FXla are contained in its light chains. FXIa activates zymogen blood coagulation factor IX in the absence of any known protein cofactor.

The nomenclature proposal contained in this document was repeatedly circulated to the working group members between 2016 and 2019. After the 2017 ISTH meeting in Berlin, the subcommittee circulated the nomenclature proposal (Table 1) to the more than 200 contributors of the Factor XI and the Contact System Subcommittee. The proposal was adopted unanimously by the Subcommittee on Factor XI and the Contact System at its business meeting during the SSC meeting in Dublin, Ireland in 2018.

\section{ACKNOWLEDGMENT}

We thank all the contributors of the SSC Subcommittee on Factor XI and the Contact System for their comments and suggestions.

\section{CONFLICTS OF INTEREST}

The authors have no relevant conflicts of interest to declare.

\section{AUTHOR CONTRIBUTIONS}

AHS and JCMM coordinated the study. AHS drafted the manuscript and JCMM created the figure with input from the other authors. All authors reviewed all drafts and have approved the final manuscript.

\section{ORCID}

Alvin H. Schmaier (iD https://orcid.org/0000-0002-3884-6234

Jonas Emsley (iD https://orcid.org/0000-0002-8949-8030

Edward P. Feener (iD https://orcid.org/0000-0003-1175-8469

David Gailani (iD https://orcid.org/0000-0001-8142-8014

Allen P. Kaplan (D) https://orcid.org/0000-0002-6566-4743

Coen Maas iD https://orcid.org/0000-0003-4593-0976

James H. Morrissey (iD https://orcid.org/0000-0002-1570-1569

Johannes J. Sidelmann (iD https://orcid.org/0000-0003-1385-4219

Joost C. M. Meijers (iD https://orcid.org/0000-0002-4198-6780

\section{REFERENCE}

1. Colman RW, Muller-Esterl W. Subcommittee on contact activation. Nomenclature of Kininogens. Thromb Haemost. 1988;60:340-341. 